\title{
The Effect of the Use of the Tradisonal Games "Nyumput Sarung, Sloppares and Ngakuk Wai" On The Improvement of Social Skills Students of Early Childhood Education in Bandar Lampung
}

\author{
Laila Maharani $^{\mathrm{a}}$, Muh. Shaleh ${ }^{\mathrm{b}}$, Aliwar $^{\mathrm{c}}$, Mumun Mulyati $^{\mathrm{d}}$, Septuri $^{\mathrm{e}}$, Dhian Tyas Untarif \\ ${ }^{\text {a, e }}$ Raden Intan Islamic State University, Bandar Lampung \\ ${ }^{b, c}$ Kendari Islamic State University, Kendari \\ ${ }^{\mathrm{d}}$ STAI Al Hikmah \\ ${ }^{\mathrm{f}}$ Bhayangkara Jakarta Raya University, Jakarta
}

Article History: Received: 10 November 2020; Revised 12 January 2021 Accepted: 27 January 2021; Published online: 5 April 2021

\begin{abstract}
In addition to social content to reintroduce traditional culture, traditional toys can restore children's social skills. The formulation of the problem in this study is how much influence the games of 'nyumput sarong, throwing slippers and ngakuk wai' in improving early childhood social skills in Bandar Lampung. This type of research is Pre-Experimental Designs (nondesign) research, which is to determine the effect of a treatment in one group, because the research conducted is to determine the effect of traditional games on the development of social skills of early childhood aged 5-6 years. Based on the results of the Mann Whitney Test, it shows that the initial measurement (Pre-Test) and the final measurement (posttest), the value of $\mathrm{p}=$ .000 or $\mathrm{p}<0.05$ is obtained, which means that Ha is accepted, which means that there is a significant difference in the level of social skills after ECE students are introduced to the three traditional games
\end{abstract}

Keywords: Traditional Games, Early Childhodd Education, Bandar Lampung

\section{Background}

Juridically, based on the provisions of Government Regulation Number 19 of 2005 concerning National education standards Article 19, states that the learning process in educational units is held in an interactive, inspirational, fun, challenging, motivating students to participate actively, and provides sufficient space for initiatives. creativity and independence according to the talents, interests, and physical and psychological development of students. Therefore, it is hoped that the learning process will provide more opportunities for students to be able to develop and boost their abilities optimally. The learning process in early childhood education units can be carried out through: (1) formal education in the form of kindergarten (TK), Raudhatul Athfal (RA), or other equivalent forms, (2) non-formal education in the form of play groups ( KB), Child Care Parks (TPA), or other equivalent forms, and (3) informal education channels in the form of family education or education organized by the environment (Depdiknas, 2003: 9).

Childhood is a relatively long period for children to learn about everything. It is during this period that children experience a developmental process in various ways, such as physical development, cognitive development, mental development, social development, emotional development, and moral development. Children have a lot of potential in each of these forms of development. The same thing according to Maharani (2017: 3) A deeper concept, namely about the potential for social awareness which is commonly referred to as social skills, is the basis for living interacting with others, working together, controlling oneself and exchanging thoughts. In order to optimize the potential for each of these children's developments, children must be facilitated in the right place, namely the right education. This education is not only formal education, but also includes education in the family, education in the community, and of course formal education in an educational institution. Early childhood education is one of the educational institutions that can facilitate children in optimizing all the potential for their development, especially in early childhood. Suyanto (2005) explains that EARLY CHILDHOOD EDUCATION aims to develop all the potential of children (the whole child) so that one day they can function as a complete human being according to the philosophy of a nation. Children can be seen as individuals who are new to the world. Therefore, children need to be guided to be able to understand various things about the world and its contents.

EARLY CHILDHOOD EDUCATION is a medium and a place to guide children in recognizing their world. EARLY CHILDHOOD EDUCATION is a very basic and strategic education, because early childhood is an important period and becomes the initial foundation for the growth and development of the next child. As stated 
by Mutiah (2010), that life in childhood with its various effects is a very important life span, especially in relation to the receipt of stimulation (stimulation) and treatment from the environment. In addition, early childhood is crucial for children in developing their potential. Similar to what was conveyed by Suryani (2007), that EARLY CHILDHOOD EDUCATION is the foundation for the development of the quality of human resources in the future.

Based on the characteristics of early childhood, social attitudes are the most dominant part in the learning process, where children interact with teachers, peers, and people around them who emphasize the development of social aspects in children so that children can adapt to their social environment. and able to be a useful member of society. By interacting with their environment, children gain experiences and meaningful new knowledge to develop their various abilities. Therefore, it is necessary to have activities in the learning process to train children to have social attitudes and train children to interact with their environment.

Social skills are abilities that do not arise by themselves, but are the result of imitation and habituation processes from the child's immediate environment. Social behavior is an activity related to other people, with peers, teachers, parents and siblings. When children relate to other people, very meaningful events occur in their life that help shape their personality, Maharani (2017: 5-6). The learning activities used must refer to the meaning of early childhood learning, namely through play and games

The development of the world today offers many types of games that are Digital, thereby reducing children's physical activity and reducing children's socialization of their environment, so that children become more individual. Very different from traditional games. Traditional games are basically games that are simple in nature and rely on the cohesiveness of each participant in playing activities. Traditional games have experienced a downturn in the last few decades, this is influenced by the development of the mindset of an increasingly advanced society that leaves old habits that are still traditional to modern habits that are easy and instantaneous. The use of traditional games as a learning medium is still not widely used in learning activities in early childhood.

Based on the survey results in Lampung Province, there are three kinds of traditional games that are currently starting to be forgotten in EARLY CHILDHOOD EDUCATION / TK learning, namely Nyumput Sarong, Lempar Selop and Ngakuk Wai. The three games are local games that prioritize cohesiveness and physical activity. Through this research, it is hoped that traditional games can be reintroduced to children, especially to EARLY CHILDHOOD EDUCATION students. In addition to social content to reintroduce traditional culture, traditional toys can restore children's social skills. The formulation of the problem in this study is how much influence the game of 'nyumput sarong, throwing slippers and ngakuk wai' in improving early childhood social skills in Bandar Lampung?

\section{Research Methodology}

\section{Research Design}

This type of research is Pre-Experimental Designs (non-design) research, which is to determine the effect of a treatment in one group, because the research conducted is to determine the effect of traditional games on the development of social skills of early childhood aged 5-6 years. The research design used in this study was the One-Group Pretest-Postest Design (Sugiyono, 2010: 74).

\section{Data collection technique}

To obtain representative and significant data information from the processes and activities that arise in the research data collection process, as well as other situations that influence it, the researcher uses several data collection techniques in this study, including the following: Observation, observation is carried out to determine the extent of the appearance of skills social activities for early childhood at the EARLY CHILDHOOD EDUCATION / TK in Bandar Lampung during traditional game activities. Observations were made from the beginning when the children did traditional game activities. Then the children's social activities during the process of implementing traditional game activities are recorded in the observation sheet. This observation sheet consists of 4 aspects of social skills that are observed, namely: communication skills, peer acceptance, building relationships with groups, and overcoming conflicts in play. The observation sheet instrument grid on the effect of traditional games on early childhood social skills was developed from a study of research theories on early childhood social skills and is based on EARLY CHILDHOOD EDUCATION material expert validation input, the following is the grid from the observation sheet instrument:

Quantitative data from the observation sheet were analyzed using descriptive statistical techniques in the form of presenting data through tables. Data analysis used non-parametric statistical techniques by performing a significance test using the Wilcoxon-signed ranking test formula. The Wilcoxon-signed ranking test was used to test the difference between the mean scores for using traditional games and those using non-traditional games. In 
this research the analysis technique. Wilcoxon is used to test the hypothesis with a significant level used is 0.05 or $5 \%$.

\section{Research Result}

Playing is an essential requirement and need for children in early childhood education, because playing is an activity carried out by every child, it can even be said that children fill a part of their life by playing. Through play, children will be able to satisfy the demands and needs of cognitive development.

Learning with the play method is a learning method that provides opportunities for children to choose activities they like, experiment with various materials or tools without coercion, imagine, solve problems, converse freely, play a role in groups, cooperate with groups, and have an enjoyable experience.

The study classified Early Childhood Education students into several classifications, namely age and gender. The frequency distribution of respondents based on age in the intervention group was that most of the EARLY CHILDHOOD EDUCATION students aged 6 years were 38 people (51\%), 30 students aged 5 years (40\%) and 7 students under 5 years old $(10 \%)$,

Based on the results of the study, it was found that the sex distribution of the respondents indicated that in the intervention group, the frequency distribution of respondents based on gender was 41 people (55\% female). Whereas in the control group, the frequency distribution of respondents based on gender was 34 men (43\%)

Before carrying out further research, researchers conducted observations and evaluations. The observations made in the classroom during learning and playing activities where during the play process the children were still not improving, then the teacher carried out an evaluation to find out how many children played satisfying and unsatisfactory. From the results of the evaluation, it is necessary to prioritize cognitive development in children.

The frequency distribution of the pre-test data on the level of social skills among EARLY CHILDHOOD EDUCATION students based on the results of the study had quite low social skills. This is indicated by the data of students who have a low level of social skills as many as 60 people (80\%) and students who have a moderate social skill level are as many as 15 students $(20 \%)$ and $0 \%$ of children who have high social skills. test in which the student is given knowledge and is involved in traditional games consecutively for two weeks ( 3 times a week @ 2 hours), there is a significant increase in social skills data. Where the level of low social skills is as many as 25 people $(33 \%)$ and students who have a moderate level of social skills are as many as 45 students $(60 \%)$ and 5 people $(7 \%)$ have quite high social skills.

\section{Conclusion}

Based on the results of the Mann Whitney Test, it shows that the initial measurement (Pre-Test) and the final measurement (post test), the value of $\mathrm{p}=.000$ or $\mathrm{p}<0.05$ is obtained, which means that there is a significant difference in the level of social skills after ECE students are introduced to the three traditional games. So that it is expected that the EARLY CHILDHOOD EDUCATION curriculum can adopt the results of this study, meaning that the EARLY CHILDHOOD EDUCATION curriculum should start to involve traditional games. Apart from having a function of preserving culture, this is also good for the development of students

\section{References}

Ajun Khamdani. (2010). Olah Raga Tradisional Indonesia. Kalimantan Barat: PT. Marga Borneo Tarigas.

Bandi Utama. A.M. (2012). Bermain Sebagai Sarana Pengembangan Aspek Sosial Pada Anak Usia Dini. Prosiding, Seminar Nasional. Yogyakarta: FIK UNY.

Desvi Yanti. (2005). Keterampilan Sosial Pada Anak Menengah Akhir Yang Mengalami Gangguan Prilaku. eUSU Respository Copyright 2005. Hal 1-19.

Dharmanto, A. Komariah, N.S. Handayani, M. Suminar, R. Untari, D.T. (2019). Analysis of tourism preferences in choosing online-base travel agents in Indonesia. International Journal of Scientific and Technology Research, 8(12), 3761-3763

Istianingsih,, Untari, D.T. (2020). Implementation of Hierarchy Analytical Process (Ahp) Method for Determine the Preferences of Choosing Online Pharmacy in Bekasi, West Java. European Journal of Molecular and Clinical Medicine, 2020, 7(2), 4858-4862

Untari, D.T \& Satria, B. (2019). Measuring website effectiveness in communicating tourism destinations in Jakarta, Indonesia. African Journal of Hospitality, Tourism and Leisure, 8(4), 1-16.

Untari, DT., Darusman, D., Prihatno, J., \& Arief, H. (2018). Strategi Pengembangan Kuliner Tradisional Betawi di DKI Jakarta. Ekuitas Jurnal Ekonomi dan Keuangan, 2(3), 313-340.

Untari, D.T. (2019). Asean tourist in bali, indonesia; trend analysis the implementation of mathematical methods in tourism sector. International Journal of Scientific and Technology Research, 8(12), 2117-2119 
Untari, D.T. (2020). The role of information technology in promotion strategy. Case in taman mini Indonesia indah and ragunan, Indonesia. Journal of Environmental Management and Tourism, 11(4), 960-966.

Gresham, Frank M.and Daniel J.Reschly.Dimensions of social competence: Method factors in the assesment of adaptive behavior, social skill, and peer acceptance, Journal of school psychology, vol.22, 1987, h.367-381.

Haerani Nur. (2013). Membangun Karakter Anak Melalui Permainan Tradisional.Jurnal UNM. Hal 1-8.

Hilmiati. (2009). Pengembangan Keterampilan Sosial Melalui Pembelajaran Puisi Pada Siswa Sekolah Dasar Kelas V SD Muhammadiyah Kolombo Yogyakarta. Tesis PPs UNY.

Kibtiyah, Maria. (2006). Efektifitas Cooperative Games Dalam Meningkatkan Ketrampilan Sosial Anak Taman Kanak-kanak (Tinjauan Psikologis). Jurnal Studi Agama dan Masyarakat, Volume 3, Nomor 1 Juni 2006. Hal $61-97$.

Ni Nyoman. S \& Nur Hayati. (2009). Permainan Tradisional Jawa Gerak dan Lagu Untuk Menstimulasi Keterampilan Sosial Anak Usia Dini. Laporan Penelitian. Yogyakarta: FBS UNY.

Nugraha, Ali \& Rachmawati, Yeni. (2005). Metode Pengembangan Sosial Emosional. Jakarta: Universitas Terbuka.

Maharani,Laila. (2017). Pengaruh Strategi Konseling dan Tipe Kepribadian Terhadap Keterampilan Sosial (Studi eksperimen pada anak Post Traumatic Stress Disorder usia 5-6 tahun di Panti Asuhan Propinsi Lampung). Sinopsis Disertasi,Pasca Sarjana Universitas Negeri Jakarta.

Sugiyono. (2013). Metode Penelitian Kuantitatif, Kualitatif, dan R\&D. Bandung: ALFABETA.

Departemen Pendidikan Nasional. (2003). Undang-Undang Nomor 20 Tahun 2003 Tentang Sistem Pendidikan Nasional, Jakarta: Depdiknas.

Mutiah, D. (2010). Psikologi Bermain Anak Usia Dini. Jakarta: Kencana Prenada Media Group.

Suryani, L. (2007). Analisis permasalahan pendidikan anak usia dini dalam masyarakat Indonesia. Jurnal Ilmiah VISI PTK-PNF, 2(1) 